\title{
DNA fingerprinting at a price at ICI's UK laboratory
}

London

WITH the opening this month of ICI's UK laboratory for DNA fingerprinting on a commercial basis, the company is moving ahead to start a similar US facility in the near future and is planning other European testing centres.

Operating in Abingdon, Oxfordshire, the UK laboratory is run by Cellmark Diagnostics, a subsidiary of ICI Diagnostics. With a staff of 22 , the laboratory can report a result in 3 weeks after the delivery of $5-\mathrm{ml}$ blood samples. About one week is needed to complete the test itself but Cellmark Diagnostics staff will be trying to streamline the test to increase its sensitivity and computerize some of the process.

\section{Japan circumvents whaling ban}

\section{London}

JAPANESE scientists have told the scientific committee of the International Whaling Commission (IWC) now meeting in Bournemouth, England, that Japan intends to continue harvesting nearly 900 whales a year under a scientific permit.

The IWC has imposed a moratorium on commercial whaling until at least 1990 , but under Article VIII of the international convention for the regulation of whaling, a member government of the IWC "may grant to any of its nationals a special permit authorizing that national to kill, take and treat whales for purposes of scientific research".

Japan's announcement that it will kill 825 minke whales and 50 sperm whales a year in the Antarctic has been criticized as a convenient way of circumventing the present ban on commercial whaling. The IWC's scientific committee questions the scientific merit of the Japanese programme.

Iceland and Korea are also carrying out whale-harvesting in the name of scientific research. Although the IWC's scientific committee concluded that Iceland's research programme "would provide only a minimal improvement in our current knowledge with respect to providing management advice", the committee cannot prevent any special scientific permits being issued.

Norway is continuing its commercial whaling programme, in defiance of the moratorium, and conservationists say that under the scientific research loophole, several ex-whaling nations including Brazil and the Philippines are considering carrying out some research of their own.

Kathy Johnston
The laboratory's initial business will come from paternity testing. DNA fingerprinting fo a child and its supposed parents is becoming recognized as the best way to determine paternity. The test is likely to settle many cases where disputed relationships are the basis of an immigration dispute.

Cellmark Diagnostics will charge $£ 105$ for each test, and can currently perform 250 a week. The test distinguishes individuals on the basis of the permutations in a series of highly variable DNA sequences scattered throughout the chromosomes. The variations are detected after fragmenting the DNA, separating the fragments by size on a gel and detecting them with radioactive DNA probes. Dr Alec Jeffries of the University of Leicester invented the test and the Lister Institute, of which he is a research fellow, holds the patents. ICI has exclusive rights to use the test commercially.

In addition to testing family relationships, DNA fingerprinting has considerable forensic potential. The Home Office Forensic Science Service has already shown that the test can be applied to sperm samples and may therefore be of use in rape cases. It will also be useful in cases where an assailant has left behind blood or tissue. The Leicestershire police are already using the test on blood samples from several thousand males, among whom they hope to identify a murderer they are hunting. There has been a long-running dispute between the Home Office and ICI as to the handling of forensic applications of DNA fingerprinting; "discussions are continuing", says ICI.

Beyond fingerprinting, ICI Diagnostics has interests in the application of DNA tests in diagnosing genetic diseases. DNA probes for several diseases are now available and many more will follow. So far, UK testing has been carried out on a noncommercial basis. Much of the research that has led to the probes and their initial diagnostic applications have been financed by charities, such as the Cystic Fibrosis Research Trust. Three pilot programmes to carry out the tests within the UK National Health Service are nearing completion with no assurance that they will continue or, indeed, be expanded. ICI may offer such tests on a commercial basis. The company also has an eye on methods for testing genetic predispositions and for applying DNA fingerprinting to the identification of cell lines and to establishing animal pedigrees.

Other companies with an interest in DNA-based tests include Lifecodes Corporation, a New York based biotech-

\section{New tide in UK oceanography?}

\section{London}

ThE Institute of Oceanographic Sciences (Bidston), one of Britain's leading oceanographic research centres, was established as an independent laboratory of the Natural Environment Research Council (NERC) on 1 April 1987 and was last week renamed the Proudman Oceanographic Laboratory (POL). This is part of NERC's new-found drive to focus on relevant applied research, but the question is whether this move by NERC will help progress in research to be made.

Dr John Woods, NERC marine sciences director, regards POL as a "key laboratory" for running strategic research programmes. The laboratory is best known for its work on the study of tides and sealevel. Work on deep-sea pressure measurements has provided a greater understanding of tides in the North Atlantic and there is a programme of in situ measurements to complement the ERS-1 altimeter data. The work on sea-level measurements is part of the World Ocean Circulation Experiment (WOCE). The three-dimensional modelling of continental shelf circulation performed at Bidston is the basis for the North Sea Project initiated by NERC. This is a strategic research programme to provide the United Kingdom with a prognostic model, with applications to marine pollution and sediment motion.

NERC's support and enthusiasm for research at $\mathrm{POL}$ has given rise to optimism about the future, but the laboratory has had a chequered history. It was founded as the Liverpool University Tidal Institute in 1919 by the physical oceanographer Professor Joseph Proudman. In 1969 it was taken over by NERC (and renamed the Institute of Coastal Oceanography and Tides) and, in 1973, linked with the National Institute of Oceanography (Wormley) and the Unit of Coastal Sedimentation (Taunton) to form the Institute of Oceanographic Sciences. (The Taunton laboratory was closed down in 1985. .)

According to some academics, NERC's involvement was greeted with optimism in 1969 , but was soon followed by disillusion and frustration. Now people will be watching to see whether NERC's latest initiative will fulfil its promise. Philippa Lloyd

nology company with several patents on fingerprinting techniques using different probes, the Boston-based company Collaborative Research, which has been accumulating large numbers of chromosome-specific DNA markers, and Celltech which has "some plans to move into the area of DNA diagnostics but is waiting for the right opportunity", according to chief executive Gerard Fairtlough.

Peter Newmark 